\title{
Diagnostic Role of Anti-Nuclear Antibodies in Rheumatic Diseases
}

\author{
Romatizmal Hastalıklarda Antinükleer Antikorların Tanısal Rolü
}

\author{
Murat BİRTANE \\ Department of Physical Medicine and Rehabilitation, Medical Faculty of Trakya University, Edirne, Turkey
}

\begin{abstract}
Autoimmune diseases result from the assault of the host antibodies against host antigens. The systemic rheumatic diseases rarely have a single pathognomonic diagnostic criterion due to multiple organ and system involvement. Interestingly, each member of this disease group may be associated with different auto antibody types. The diagnosis depends on clinical features, as well as the auto antibodies detected in the sera of the patients. Antinuclear antibodies (ANA) usually target the specific antigens in the nuclear part of the cell, although they can sometimes show affinity against all types of subcellular structures and cell organelles including cell surfaces, cytoplasm, nuclei, or nucleoli. These may provide important data for an upcoming rheumatic disease, be valuable in the diagnosis and prognosis prediction when they are detected in the sera. Simply, ANA can be measured in two ways; one is the generic ANA for overall evaluation and the second is specific antibody detection for specific diseases. Generic ANA measurement can be performed using immunofluorescence techniques and ELISA. If it is positive, specific antibodies can further be investigated by automated methods. The immunofluorescence ANA testing is still gold standard. They show significance when detected in high titers in clinically suspected patients. Furthermore, staining patterns may provide information for the specific disease, indicating the cellular targets of specific antibodies. Generic ANA is highly sensitive for systemic lupus erythematosus (SLE) and scleroderma, while its specificity is lower in these pathologies. ANA may be found positive in healthy people and patients with many other pathological conditions. Therefore, they may be important to rule out the disease. In contrast to generic ANA, specific antibodies are usually specific for related diseases with a low level of sensitivity. Thus, its presence helps diagnosis, however its absence may not be sufficient to exclude the disease. The main antibodies in this category are anti-dsDNA, antiSmith (Sm), and antiribonucleoprotein (RNP) in the diagnosis of SLE; antihiston antibodies for drug-induced SLE; anti-Ro/SSA - anti La/SSB antibodies for Sjögren syndrome; and anticentromer, anti Scl 70 antibodies for scleroderma.
\end{abstract}

Key words: Anti-nuclear antibodies; diagnosis; rheumatic diseases.
Otoimmün hastalıklar, konak kendi antijenlerine saldırması sonucunda meydana gelir. Sistemik romatizmal hastalıklar, birden fazla organ ve sistemi tuttukları için, nadiren patognomonik bir tanısal kritere sahiptirler. İlginç olarak, bu hastalık grubunun her biri, farklı otoantikor tipi ile ilişkilendirilebilir. Tanı, klinik özelliklerin yanı sıra, hastanın kanında saptanan spesifik antikorlar ile konur. Otoimmün hastalıklarda saptanabilen antinükleer antikorlar (ANA) hücrenin hücre yüzeyi, sitoplazma, nükleus ve nükleolus gibi tüm subselüler yapılarına karşı benzerlik gösterebilmesine karşın, genellikle hücrenin nükleer kısmındaki spesifik antijenleri hedef alırlar. Bunlar kanda tayin edildiklerinde ortaya çıkmakta olan bir romatizmal hastalığı işaret edebilirler; tanının konmasında belirleyici olabilirler ve prognoz ile ilgili önemli bilgiler sağlayabilirler. Basit olarak ifade etmek gerekirse; ANA iki şekilde ölçülebilir. Birincisi jenerik olarak tüm antikorların değerlendirildiği ANA ölçümü, diğeri de hastalıklara özgün olabilen spesifik antikor tayinidir. Jenerik ANA ölçümü, immünofloresan teknikleri ve ELISA yöntemi ile yapılabilir. ANA pozitif ise, spesifik antikorlar otomatize yöntemler ile araştırılabilir. İmmünofloresan ANA tayini altın standarttır. Klinik şüphesi olanlarda yüksek titrelerde saptanırsa anlamlıdır. Ayrıca ANA boyanma paternleri de spesifik antikorların hücrenin hangi bölgeleri ile reaksiyona girdiğini göstererek spesifik hastalık hakkında fikir verebilir. Jenerik ANA sistemik lupus eritematozus (SLE) ve skleroderma için oldukça duyarlı iken, bu hastalıklarda özgüllüğü düşüktür. ANA sağlıklı insanlarda ve birçok başka patolojik durumda pozitif bulunabilir. Bu nedenle bunlar hastalığın tanısının dışlanmasında önemli olabilir. Spesifik antikorlar da genellikle işaret ettikleri hastalıklar için, Jenerik ANA'nın aksine spesifiktir ve duyarlılıkları düşüktür. Bu nedenle, varlıkları hastalığın tanınmasını sağlarken, yoklukları ekarte ettirmez. Bu antikorların başlıcaları SLE tanısında önemli olan anti-dsDNA, antiSmith (Sm) ve antiribonükleoprotein (RNP), ilaca bağlı lupus tanısında antihiston antikorlar, Sjögren sendromu tanısına ışık tutabilen anti-Ro/SSA - anti La/SSB ve skleroderma tanısında yeri olan anticentromer ve antiScl 70 antikorlardır.

Anahtar sözcükler: Antinükleer antikorlar; tanı; romatizmal hastalıklar.

\section{Received: May 3, 2012 Accepted: May 8, 2012}

Correspondence: Murat Birtane, M.D. Trakya Üniversitesi Tıp Fakültesi, Fizik Tedavi ve Rehabilitasyon Anabilim Dalı, 22030 Edirne, Turkey.

Tel: +90 284 - 2357641 / 4711 e-mail: mbirtane@hotmail.com

(C2012 Turkish League Against Rheumatism. All rights reserved. 
An autoimmune disease occurs when the antigens of an organism are attacked by the autoantibodies as a result of disturbed self-tolerance on multifactorial basis which involves inflammatory pathogens, altered receptors, radiation, or genetic background. ${ }^{[1]}$ Generally this relationship leads to humoral or cell-mediated immune reactions against one or more of the body's self-structures. ${ }^{[2]}$

It is unusual to diagnose a systemic rheumatic disease (RD) with a single pathognomonic clinical sign or finding since these diseases frequently involve multiple body parts and reveal a rich clinical symptomatology. ${ }^{[3]}$ The diagnosis is mainly based on criteria sets which need satisfying, including clinical, laboratory, and radiological parameters. A competent physician should be proficient regarding the specific characteristics of specific RDs and their subgroups since they contain some dissimilar properties. ${ }^{[3]}$ As opposed to organ-specific autoimmune diseases which target one organ, autoantibodies may be produced against many different cell groups, especially in systemic RDs. ${ }^{[3]}$ The justification of the presence or absence of these diseases mainly depends on the verification of disease-related symptomatology as well as the detection of sensitive or specific antibodies in the sera of suspected patients. ${ }^{[1]}$

Antinuclear antibodies (ANA) usually target specific antigens in the nuclear part of the cell, although they can sometimes show affinity against all types of subcellular structures and cell organelles, including the cytoplasm, nuclei, nucleoli, or cell surfaces. The most recognized clinically useful antigens are RNA-protein or DNA-protein complexes. ${ }^{[4]}$

In clinical circumstances, the detection of ANAs are important for three reasons: specifying the diagnosis with determination of disease-specific autoantibodies, establishing appropriate monitoring and prognosis in some RDs, and determining an impending disease in an asymptomatic individual. ${ }^{[5]}$

\section{GENERIC ANA EVALUATION}

\section{Immunofluorescence (IF) techniques}

Lupus Erythematosus (LE) Cell: Systemic lupus erythematosus (SLE) was first described as a systemic $\mathrm{RD}$ at the beginning of the 1940s. At the end of that decade, it was noted that patients with SLE had previously unknown cells in their bone marrow called LE cells. These cells are polymorphonuclear leukocytes which have capability to phagocyte the bare nuclei of other leukocytes with the help of auto antibodies, thus providing opsonization to the liberated nuclear material of the target cell. ${ }^{[6]}$ Although the detection of LE cells was helpful in the diagnosis of SLE by also preventing invasive biopsies, the results were neither sensitive nor specific for the diagnosis of SLE. ${ }^{[7]}$

The discovery of ANAs by IF techniques: When it was understood that the causitive factor of the LE phenomenon is the autoantibodies targeting the host antigens, ANA testing was then introduced by using IF techniques on animal substrates. ${ }^{[7]}$ This method is still the primary method used for detecting ANAs. ${ }^{[8]}$ In this process, a slide is prepared containing fixed cells which serve as an antigen source, and these are incubated afterwards with human sera. If a reaction occurs, then the added fluorochrome- conjugated antibodies against human immunoglobulin $G$ ( $\operatorname{IgG}$ ) bind the complex, and this allows a specific, shiny pattern that can be observed under a light microscope in various titers. ${ }^{[4]}$

A rodent or mouse tissue was used initially as the antigen source. This method markedly increased the sensitivity for SLE diagnosis; however, the specificity decreased. ${ }^{[7]}$ Even healthy people or people with other diseases showed more positive results. The sera of the patients were diluted to overcome the problem, and 1/40 dilution was accepted as the cut-off point for positive results. ${ }^{[7]}$ The titer is the highest dilution by which the staining can still be observed. Since SLE patients have higher autoantibody concentrations, they could be detected even if the sera were thinned, but this was not a definitive solution. These first IF attempts revealed that autoantibodies targeting different antigens showed various patterns under a light microscope which are useful for differential diagnosis of autoimmune diseases. ${ }^{[7]}$

Over the past decades, the rodent tissue has been replaced by the HEp-2 cell line (human laryngeal carcinoma) for routine ANA testing. ${ }^{[6,7]}$ This substrate increased the sensitivity because of the expression of more relevant nuclear antigens in the human tumor cells, including the Ro/SSA antigen which was the source of the ANA-negative lupus phenomenon. Moreover, centromeres, and nucleolar activity are more readily viewed in HEp-2 cells, so it became usual to detect positive results on HEp-2 cells in patients with reported negative results when rodent tissue substrates were used. Also, the cut-off point for the titer was raised to dilutions of $1 / 80$ or higher. ${ }^{[7]}$

Appropriate reporting of IF ANA depends on three important parameters: 
1. The type of substrate used [The type of fixation, conjugation (a-IgG, a-IgG + a-IgM), microscopy, and subjectivity of the observer can also influence the convenience of the results].

\section{The titer of the positive result}

3. The pattern and intensity of staining

Titer: In this retrospective study, there were positive results for ANA in $31.7 \%$ of healthy people in $1 / 40$ dilutions; $13.3 \%$ in $1 / 80$ dilutions, $5 \%$ in $1 / 160$ dilutions, and $3.3 \%$ in $1 / 320$ dilutions. ${ }^{[9]}$ Therefore, it is possible that higher titers of ANA are clinically more relevant. As specificity increases with higher dilutions, it is rational to increase the cut-off point from $1 / 40$ to 1/160 dilutions with the presentation of the Hep2 cell substrate. Of course, the higher specificity may lessen the value of sensitivity, so to establish a threshold value, well-balanced sensitivity and specificity values are needed. ${ }^{[4,6]}$ The definite cut-off point should be settled by individual laboratories by taking into account the substrate used, secondary antibodies, buffer, fluorescent microscope, and other conditions. ${ }^{[4]}$

Although the higher titers of positive ANA increase the likelihood of the presence of an $\mathrm{RD}$, it should be noted that high titers do not always show higher disease activity and severity. For example, a patient with Raynaud's syndrome may have high titers of positive ANA while another patient with a serious organ involvement may not. One of the specific autoantibodies, such as antidouble-stranded DNA (anti-dsDNA), usually shows relatively low titers in ANA, whereas others, such as anti-U1RNP and centromere, may lead to very high titers of positive ANA, irrespective of the clinical and life-threatening severity. ${ }^{[4]}$ Monitoring the disease activity is also not feasible with ANA because it shows great fluctuations without regard for changes in disease activity. ${ }^{[10]}$

The staining pattern: The staining pattern of antibodies is discriminative since it is determined by a specific target antigen. These patterns are usually reported as either nuclear, centromere, or nucleolar. The cytoplasmic pattern is difficult to interpret, and it should be known whether the laboratory staff is capable of reporting it appropriately or not. ${ }^{[4]}$ Among more detailed nuclear staining patterns, homogenous, speckled, peripheral, and nucleolar patterns are more commonly observed and of clinical importance. ${ }^{[6]}$ The patterns and related RDs can be seen in Table $1 .^{[10]}$ A homogeneous/peripheral pattern shows antibodies which target histone/dsDNA/chromatin, whereas most other antibodies show a speckled pattern in many RDs with different sizes and densities (fine or dense). ${ }^{[4,10]}$ Nucleolar and centromeric patterns are more specific, especially for different forms of scleroderma. The former shows reactions to nucleolar RNA and RNA polymerase I, and the latter reacts to centromere (Table 1). ${ }^{[10]}$ It is very important to know the competence of the laboratory staff in interpreting the patterns. Knowing what will and will not be reported as well as their specific weaknesses is crucial. In general, ANA reports can not be definitively trusted since the evaluation is dependent on the operator. ${ }^{[10]}$ Because of this and because more relevant tests, such as immunodiffusion, immunoprecipitation, radioimmunoassay (RIA), hemagglutination, and enzyme immunoassay (EIA), for detecting specific autoantibodies to specific nuclear antigens are now widely available, interpretation of patterns has become much less important clinically and is being gradually replaced by these automated tests. ${ }^{[10]}$

The other frequent tests for generic ANA evaluation [enzyme immunoassay (EIA) and enzyme-linked immunosorbent assay (ELISA)] are now routinely used. These methods can also be utilized to detect

Table 1. Common immunofluorescence antinuclear antibodies patterns associated with specific diseases ${ }^{[6]}$

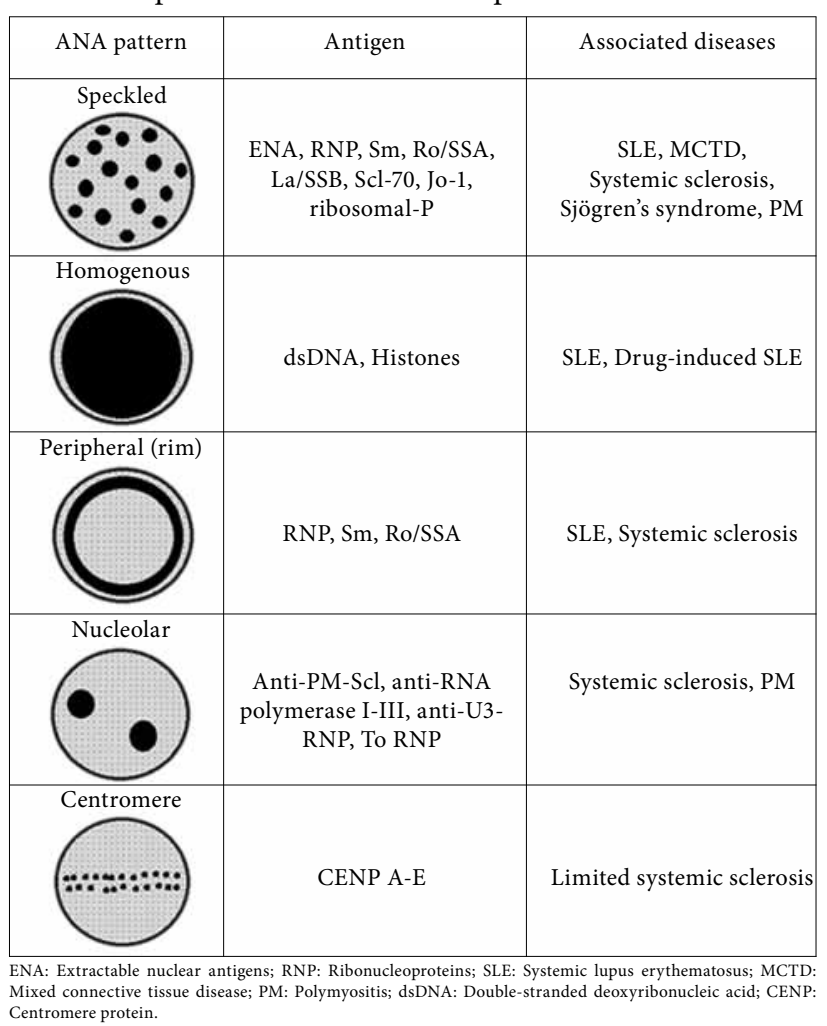


single autoantigens, such as dsDNA, Ro/SSA, La/SSB, Scl-70. These tests are automated, easy to perform, and do not necessitate highly qualified laboratory staff. ${ }^{[6]}$ Although there is an agreement of up to $90 \%$ between ELISA and IF tests for ANA detection, some reports reveal that ELISA may miss some antigens, such as anti-SSA/Ro. ${ }^{[6]}$ This problem can especially be seen in low titer ANA positive sera. Widespread false positive results by ELISA are the other problems reported by some authors. ${ }^{[1]}$

\section{Techniques for specific subtyping}

It is currently accepted that ANA contains two major types of antibodies. The first group includes antibodies against DNA and histones which are indicative of SLE and drug-induced lupus erythematosus (DILE), respectively. The second group includes autoantibodies to extractable nuclear antigens (ENA) which are obtained by extracting them from nuclei with saline. The autoantibodies to Smith antigen (Sm) ribonucleoproteins (RNP), Ro/SSA or La/SSB, Scl-70, histidyl-tRNAsynthetase (Jo-1), and PM1 are in this group, and they have different sensitivity and specificity values depending upon the underlying specific RD. ${ }^{[6]}$

Other new and emerging antibodies such as topoisomerase-I (topo-I), centromere protein (CENP)-B, RNA polymerase I-III (RNA-pol I-III), MU, $\mathrm{TM}, \mathrm{Ku}, \mathrm{Mi}-2$, and RA33 have also been identified. ${ }^{[6]}$

Anti-dsDNA detection: Three main methods are available for the detection of anti-dsDNA which are the Crithidia luciliae immunofluorescence (CLIF) method, Farr assay, and ELISA. ${ }^{[6]}$ The CLIF method is an IF test using a specific substrate, C. Luciliae, that is hemoflagellate. ${ }^{[12]}$ This substrate contains only dsDNA in high concentration, and this test has higher specificity for the diagnosis of SLE than ELISA. The Farr assay is a radio-labeled assay which reveals the proportion of antibody in the sera in the most reliable manner, but it has the inherent risks associated with using a radioactive material. ${ }^{[6]}$

Tests for detection of other ANA subtypes: Antinuclear antibodies are helpful for the differential diagnosis of RDs. ${ }^{[13]}$ The main methods used for detection of specific antibodies are gel precipitation assays, passive hemagglutination, western (immuno-) blot, multiplex immunoassay, flow cytometry, and antigen microarray. ${ }^{[6]}$ All of these methods investigate the existence of specific antibodies as specific markers for each autoimmune disease which might play an important role in the pathogenesis. Multiplex detection of many of them in the sera of the patients simplifies the detection procedures. ${ }^{[14]}$ These systems use two major arrays, one being planar and the other nonplanar. Planar arrays consist of systems constituted by microspots on slides, polystyrene microplates, and linear immunoblot systems on nitrocellulose membranes. The non-planar arrays are suspension arrays using microparticles recognized by laser fluorometry in flow cytometers or barcoded particles showing similar or better performances when compared with conventional immunometric systems. ${ }^{[15]}$ Antigen microarray, an emerging nanotechnology technique, may also be promising for the discovery and evaluation of novel autoantibodies. ${ }^{[6]}$

Which is preferable? Automated ANA testing or IF ANA testing. Automated ANA tests discriminate positive ANA results with a good specificity, can target specific antigens, measure the level of multiple antibodies in a single serum sample, obtain fast results, allow for many samples to be processed at the same time, do not need trained operators, and are prone to new scientific developments. ${ }^{[6]}$ However, the low sensitivity issue has not yet been resolved. Automated tests cannot detect many of the unknown antigens stained readily with the IF method, which may be relevant for the diagnosis of RDs like SLE. Moreover, native shapes of antigens in a living cell may be better recognized compared to synthetic antigens on a synthetic bead in a machine. According to the American College of Rheumatology Position Statement, the IF ANA assay is still the gold standard for ANA testing with greater sensitivity than solid phase assays. It also points out that many commercial laboratories and some hospital laboratories have switched their ANA screening test to solid phase immunoassays and that laboratories should indicate the method used when reporting ANA results. $^{[8]}$

\section{CLINICAL INTERPRETATION OF ANA TESTING}

Basic statistics: The diagnostic value of tests. The sensitivity of a test is the proportion of affected individuals with a positive test. In other words, sensitivity refers to how good a test is at correctly identifying people who have the disease. Specificity is the proportion of unaffected individuals with a negative test. Simply put, it is concerned with how good the test is at correctly identifying people who are well. ${ }^{[16]}$ Extreme values are useful for verifying the diagnosis. For a high specific test, positive results 
confirm the disease, and for a high sensitive test, negative values rule it out. The likelihood ratio (LR) is one of the best ways to reveal diagnostic accuracy. The rate of probability of a positive test in patients with a given disease to the probability of the same test in patients without the disease is named as positive LR. ${ }^{[17]}$ The LR takes both the sensitivity and specificity of the test into account and provides an estimation of the change in odds for having or not having a disease. A positive LR value shows how much the odds of the disease increase in cases in which the test is positive. Conversely, a negative LR reveals the odds of the disease decreasing when the test is negative. ${ }^{[17]}$ Likelihood ratio values between 0 and 1 argue against the diagnosis. The closer the LR is to 0 , the less likely the disease is present. When the LR is equal to 1 , it has no diagnostic value while values greater than 1 point to a more convincing diagnosis.

It is crucial to estimate the pretest probability of an $\mathrm{RD}$ with the help of the patient's history and a physical examination. Afterwards, we can estimate the post-test

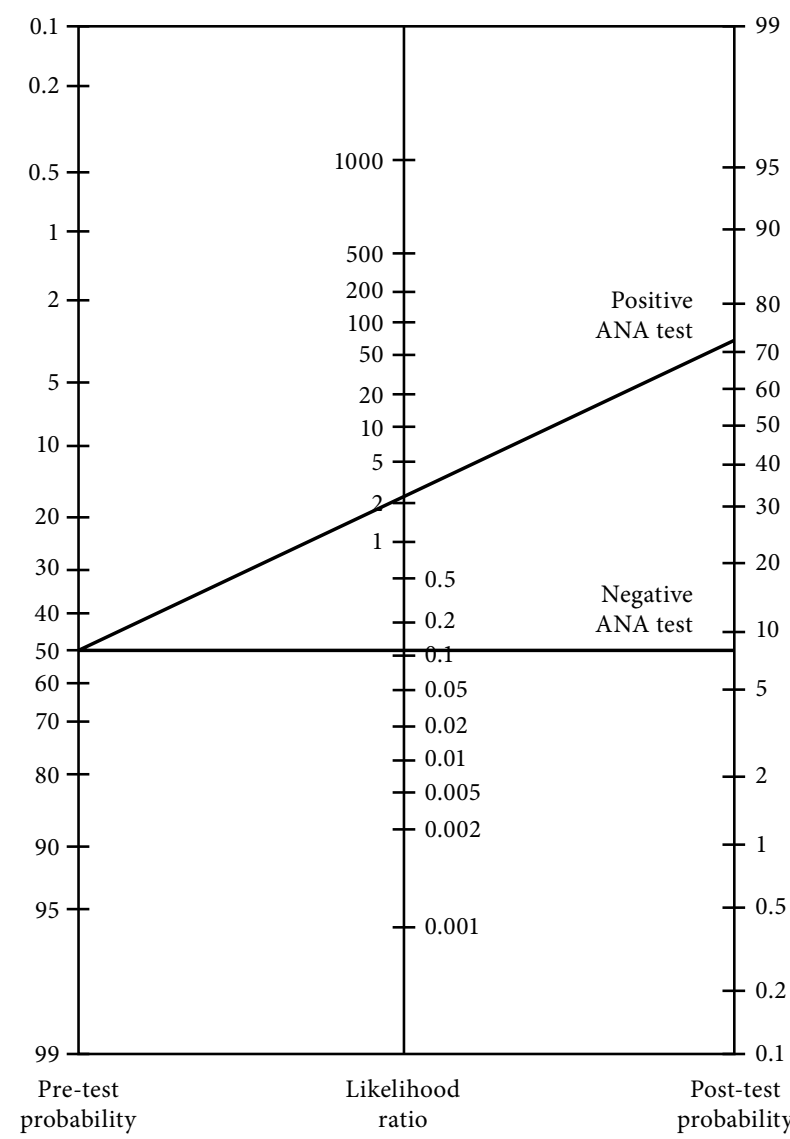

Figure 1. The likelihood nomogram used in systemic lupus erythematosus with an antinuclear antibodies test. probability by using a diagnostic test with a given LR on an LR normogram (Figure 1) ${ }^{[18]}$ An example of this is below:

+ LR of ANA test is 2.2 for SLE while the -LR is 0.11 .

A patient with a $50 \%$ pretest probability of having SLE will have an approximate post-test probability of $70 \%$ if the test is positive, and the post-test probability will be under $10 \%$ if the test is negative. The negative test is more valuable under these circumstances.

Interpretation of ANA test: An ANA test should be requested only if there is a suspicion of an $\mathrm{RD}$. It is not wise to perform the test on an asymptomatic patient or a patient with musculoskeletal symptoms not related to an RD. If a patient has arthritis, pleuritis, pericarditis, a photosensitive rash, renal failure, hemolytic anemia, immune thrombocytopenia or neutropenia, skin lesions resembling scleroderma, dermatomyositis or vasculitis, myositis, Raynaud's syndrome, or neurological findings, then an ANA test should be ordered.

Although the performance of ANA findings in the diagnosis of RDs is not as definitive as other studies which have reported various sensitivity and specificity values, it has been consistently shown that these findings have high sensitivity for SLE and scleroderma. The sensitivity of the ANA test for the diagnosis of SLE is $93 \%$ and for scleroderma $85 \%$ while lower rates exist for polymyositis/dermatomyositis (61\%), Sjögren's syndrome (SS) (48\%), and secondary Raynaud's syndrome (64\%). ${ }^{[10]}$ Although the sensitivity values of ANA are high or moderate, the specificity values are relatively lower $(57 \%$ for SLE, $54 \%$ for scleroderma). ${ }^{[10]}$ Positive ANA findings are common for many RDs, autoimmune diseases, or even for healthy people. ${ }^{[6]}$ Elderly female patients, pregnant women, and people with a family history of RDs have a much higher probability of having a positive ANA test. ${ }^{[6]}$ Also, an ANA test finding of positive can be found in rheumatoid arthritis (RA), multiple sclerosis, idiopathic thrombocytopenic purpura, primary biliary cirrhosis, autoimmune thyroiditis, discoid lupus, infectious diseases, malignancies, and fibromyalgia, but it does not significantly contribute to the diagnosis. ${ }^{[6]}$ Some drugs, such as hydralazine, procainamide, immunomodulators, antithyroids, isoniazid, beta-blockers, minocycline, and penicillamine, can also elevate the levels of ANA.

It has been reported that up to $20 \%$ of healthy people have positive ANA. Interestingly, of these healthy 
individuals, 33\% had specific antibodies directed against the dense fine speckles 70 (DFS70) antigen, which ANA positive patients with a RD usually do not have. Therefore, it can be argued that ANA positive patients with a dense fine speckled pattern have a higher probability of being in good health. ${ }^{[19]}$

In the clinical judgement of RDs, there are situations in which ANA testing is very helpful. A negative ANA is an important sign to rule out SLE (negative LR 0.11 for SLE), but the positive LR is not so significant (positive LR: 2.2 for SLE) and contributes less to a positive diagnosis. ${ }^{[7,10]}$ Scleroderma (systemic sclerosis) usually exhibits a specific set of clinical symptoms and findings, and positive ANA is not one of them. However, 60 to $90 \%$ of the patients with scleroderma have positive ANA, and this supports the diagnosis (positive LR: 1.86 for scleroderma). ${ }^{[7,10]}$ A negative ANA is again more meaningful as its negative $L R$ is 0.27 for scleroderma. ${ }^{[10]}$ A negative ANA test might point to other fibrosing illnesses, such as linear or local scleroderma, eosinophilic fasciitis, and scleredema. ${ }^{[7]}$

In the diagnosis of SS and idiopathic inflammatory myositis, ANA testing is somewhat useful, with the sensitivity for the diagnosis being between $40 \%$ and $70 \%$ but with a low specificity ${ }^{[7]}$ A positive ANA test supports the diagnosis, and a negative ANA test does not rule it out.

The ANA test is also useful for monitoring and estimating the prognosis in juvenile chronic arthritis (JCA), Raynaud's syndrome and antiphospholipid antibody syndrome (APS). In JCA patients with pauciarticular or polyarticular involvement, a positive ANA finding increases the probability of the development of uveitis by up to $20-40 \%{ }^{[7]}$ Raynaud's syndrome may develop as a secondary clinical condition to SLE, scleroderma, and RA in $19 \%$ of the patients. ${ }^{[7]}$ This probability increases to $30 \%$ if the ANA test is positive and decreases to $7 \%$ if the test is negative. ${ }^{[20]}$ The positive ANA increases the likelihood that APS is secondary to SLE. ${ }^{[7]}$

Antinuclear antibody testing is an intrinsic part of the diagnostic criteria in drug-induced SLE and mixed connective tissue disease (MCTD) as the sensitivity is very high (approximately 100\%) for these diseases. ${ }^{[7]}$

\section{In conclusion: ${ }^{[4,6,7,10]}$}

a) An ANA test should not be ordered if there is no clinical suspicion of an RD since ANA is not specific in the normal population. b) The presence of fatigue, back pain, and osteoarthritis symptoms are not indications of the need for ANA testing.

c) Antinuclear antibody testing does not add anything to the diagnostic process of RA and, therefore, should not be used in this occasion.

d) Higher titers are more meaningful.

e) Nucleolar and centromeric patterns are more specific and indicative of various forms of scleroderma.

f) Antinuclear antibody testing is usually performed once. Positive tests should not be repeated. As levels of the antibodies fluctuate, regardless of the disease activity, there is no need to repeat positive tests for monitoring.

g) If there is a suspicion of an emerging $\mathrm{RD}$, previous negative tests can be repeated.

h) It should be kept in mind that some anti-Ro positive patients may have negative ANA. Further ENA testing can be performed, even if the ANA testing is negative, in patients with sicca symptoms.

i) Positive ANA is usually sensitive while further specific antibody tests are more specific for diagnosis of RDs.

j) Diagnosis can be better established by the use of ENA tests since they can sometimes estimate disease activity and prognosis.

\section{SUBTYPE ANTIBODIES USED IN RHEUMATOLOGY}

Specific antibodies to certain nuclear structures of the cell generally have high specificity for certain RDs. They are useful verifying the presence of the disease, but not for ruling it out since their sensitivity is not so high when compared with generic ANA (Table 2). ${ }^{[10]}$

\section{Anti-dsDNA antibodies}

DNA antibodies can be against single-stranded (ssDNA; denatured) or double-stranded (native) DNA. ${ }^{[21]}$ Anti-ssDNA antibodies have been separated from the kidneys of patients with proliferative nephritis and may play a role in the pathogenesis. ${ }^{[22]}$ However, they are nonspecific and do not correlate with disease activity. On the other hand, the testing for the presence of anti-dsDNA is beneficial, as this antibody has been designated as one of the diagnostic criteria for SLE by the American College of Rheumatology. It has been reported that it is $97.4 \%$ specific and $57.3 \%$ sensitive for SLE. It has a positive LR of $16^{[10,23]}$ and is very rare 


\begin{tabular}{|c|c|c|c|c|c|}
\hline Specific ANA & Associated RD & Sensitivity & Specificity & $\begin{array}{c}\text { Positive } \\
\text { likelihood ratio }\end{array}$ & $\begin{array}{c}\text { Negative } \\
\text { likelihood ratio }\end{array}$ \\
\hline Anti-dsDNA & Systemic lupus erythematosus & 57 & 97 & 16.3 & 0.49 \\
\hline Anti-Sm & Systemic lupus erythematosus & $25-30$ & $\operatorname{High}^{*}$ & * & * \\
\hline Anti Ro/SSA & $\begin{array}{l}\text { Sjögren's syndrome, } \\
\text { subacute cutaneous SLE, } \\
\text { Neonatal lupus syndrome }\end{array}$ & $8-70$ & 87 & * & * \\
\hline Anti La/SSB & $\begin{array}{l}\text { Sjögren's syndrome, } \\
\text { subacute cutaneous SLE, } \\
\text { Neonatal lupus syndrome }\end{array}$ & $16-40$ & 94 & * & * \\
\hline Anti-U3-RNP & Systemic sclerosis & 12 & 96 & 3 & 0.92 \\
\hline Anticentromere & $\begin{array}{l}\text { Limited cutaneous } \\
\text { systemic sclerosis }\end{array}$ & 65 & 99.9 & 650 & 0.4 \\
\hline Scl-70 & Systemic sclerosis & 20 & 100 & $>25$ & 0.8 \\
\hline Jo-1 & Polymyositis & 30 & 95 & * & * \\
\hline
\end{tabular}

in healthy people and in patients with other diseases (negative LR: 0.49). Anti-ssDNA is also negative in many forms of DILE. When positive, it is very useful for diagnosing SLE, but its absence does not rule out the disease. Its presence is looked for when there is a pretest probability for SLE and when the generic ANA test is positive. It can give information about the disease activity (positive LR: $\sim 4$ ), and high levels of anti-ssDNA may be associated with the development of lupus nephritis and vasculitis (positive LR: 1.7). ${ }^{[24]}$ It can be detected many years before the clinical phase of the disease, and elevated levels may well predict the disease exacerbation in SLE. ${ }^{[25]}$ The measurements can be repeated at one-three-month intervals if the disease is active and at 6-12 month intervals if the activity is low. ${ }^{[23]}$

\section{Anti-Sm antibodies}

Anti-Sm and anti-RNP antibodies bind to related but distinct antigens. The Smith antigens are a series of nuclear nonhistone proteins complexed with small nuclear RNAs. The complexes are called small nuclear ribonucleoprotein particles (snRNPs) and are important in the splicing of precursor messenger RNA. ${ }^{[24]}$ Anti-Sm antibodies are mostly found only in SLE patients. Although their sensitivity is not so high for SLE since they can only be detected in $25-30 \%$ of the patients, their specificity is very high, making the test very useful for confirming the diseases but not successful for ruling them out. ${ }^{[10]}$ They are usually associated with high titers of ANA and can not be used for monitoring the disease in the way that is possible for anti-dsDNA. ${ }^{[24]}$ Most laboratories use either ELISA or hemagglutination to detect these antibodies. ${ }^{[26]}$

\section{Anti-RNP antibodies}

The anti-RNP system binds to antigens containing only U1-RNA that are different from but related to Sm antigens. ${ }^{[2]}$ Anti-RNP antibodies are detected in $30-60 \%$ of SLE patients but are not specific for them. They are also associated with Raynaud's syndrome and a milder probability of renal involvement. ${ }^{[27]}$ They are useful in diagnosing MCTD with an unknown performance since the presence of the anti-U1 RNP antibody is one of the criteria for MCTD. ${ }^{[10]}$ The antibodies can be found in low titers in scleroderma, and anti-U1 RNP may indicate pulmonary fibrosis and joint involvement in this connective tissue disease. ${ }^{[28]}$

\section{Anti-histone antibodies}

Histones are basic proteins which bind cellular DNA. They are detected in 95\% of DILE patients and $50-70 \%$ of those with SLE. Systemic DILE patients usually have positive sera for ANA and anti-histone antibodies but not for anti-ds DNA and anti-ENA. ${ }^{[29]}$ On the other hand, the positive sera for these antibodies do not necessarily mean that the patient has the disease since many patients having the antibodies are asymptomatic. $^{[10]}$

\section{Anti-chromatin (anti-nucleosome) antibody}

Chromatin is the native complex of histones and DNA. Anti-chromatin (anti-nucleosome) antibodies 
are reported to be detected in 50-90\% of SLE patients. ${ }^{[30]}$ Some of these antibody subsets are pathogenic and may take part in the nephritogenic process in SLE. ${ }^{[31]}$

\section{Anti Ro/SSA - anti La/SSB antibodies}

Anti Ro/SSA and anti La/SSB antibodies target cellular proteins complexed with small nuclear RNAs. They are frequently seen in SLE and SS patients, ${ }^{[10]}$ and their presence is one of the criteria for the diagnosis and classification of SS. ${ }^{[14]}$ They are rare in the general population and in diseases other than SS and SLE, although they can be detected in scleroderma, polymyositis, MCTD, and RA. Anti Ro/SSA and anti $\mathrm{La} / \mathrm{SSB}$ antibodies can also be found in patients who satisfy SLE criteria with negative ANA. ${ }^{[10]}$

Anti Ro/SSA antibodies are found in 50\% of patients with SLE and are associated with photosensitivity, cutaneous vasculitis, and interstitial lung disease. ${ }^{[21]}$ They can be detected in $40-90 \%$ of primary SS patients but not as frequently in patients with secondary SS $(10-15 \%){ }^{[14]}$ In addition, they are associated with neonatal lupus and congenital heart block.

Anti La/SSB antibodies generally show parallelism to anti Ro/SSA antibodies. They are found in $10-15 \%$ of SLE patients and $20-50 \%$ of primary SS patients. The mothers of babies born with congenital heart block have an $80 \%$ probability of exhibiting anti Ro/SSA and anti La/SSB antibodies, even in the absence of an RD. Only $1 \%$ of all seropositive mothers will have babies with neonatal lupus syndrome or congenital heart block. $\cdot^{[10]}$

The antibodies should be measured under the following conditions: 1) suspicion of SLE and primary SS (even if the ANA is negative), 2) mothers of babies with neonatal lupus and congenital heart block, and 3) patients with SLE who are planning to get pregnant.

\section{Anti-centromere antibodies}

Autoantibodies to the centromere proteins were first described in $1980 .{ }^{[32]}$ There are three major centromere proteins: CENP-A, B, and C, ${ }^{[33]}$ with the major target being CENP-B. They are associated with limited cutaneous systemic sclerosis and the CREST (calcinosis, Raynaud's syndrome, esophageal dysmotility, sclerodactyly, telangiectasia) variant. ${ }^{[34]}$ Compared with healthy people, the specificity for CREST is high while the sensitivity is low (99.9\% versus $65 \%$, respectively). ${ }^{[10]}$ The disease is almost always diagnosed in cases in which the test is positive, but the discriminative value from diffuse systemic sclerosis is not so prominent (positive LR: 3.9, negative LR: 0.5 ). When found in patients evaluated for Raynaud's syndrome, anti-centromere antibodies can predict the future development of scleroderma (positive LR: 3.5 ). ${ }^{[10]}$ However, they are more distinctive for ruling out CREST (negative LR: 0.2). They are also associated with a lower frequency of interstitial pulmonary fibrosis. ${ }^{[35]}$ It has been reported that 5.6\% of SLE patients show positive sera for anti-centromere antibodies. ${ }^{[33]}$

\section{Anti-scl-70 antibodies}

More than $90 \%$ of scleroderma patients have positive sera for ANA. The nucleolar ANA pattern is common in patients with diffuse scleroderma and the centromere pattern for CREST syndrome. Autoantibodies to Scl-70 target against topo-I. ${ }^{[36]}$ Anti-Scl-70 is detected in about $20-40 \%$ of systemic sclerosis patients and may increase the risk for pulmonary fibrosis, diffuse cutaneous involvement, and nephropathy. Although the sensitivity is low, specificity approaches $100 \%$. If the antibodies are detected in patients with Raynaud's syndrome, scleroderma is almost always diagnosed since specificity is $98 \%$ and positive LR is 10 . However, the test is useless for ruling out the disease as the sensitivity is low $(28 \%)$ and the negative LR is $0.7 .^{[10]}$

\section{Anti-nucleolar antibodies}

The nucleolar IF pattern is highly specific for scleroderma. Specific antibodies leading to the formation of this pattern are anti-PM/Scl antibodies which signify the following: overlap syndromes, scleroderma/polymyositis, anti-Th/To antibodies associated with limited cutaneous types, the presence of pulmonary arterial hypertension, antiRNA polymerase I with rapidly progressive types, anti-RNA polymerase III with diffuse types with little visceral involvement, anti-U3-RNP with diffuse cutaneous types, and pulmonary artery hypertension. ${ }^{[37]}$

\section{Other antibodies}

The presence of anti-neutrophil cytoplasmic antibodies (ANCAs) is helpful in the diagnosis of vasculitic diseases. These antibodies show two types of IF patterns: cytoplasmic (cANCA) and perinuclear (pANCA). The antigens proteinase-3 (PR3) and myeloperoxidase (MPO) are used in ELISA testing. The cANCA has a high sensitivity for the diagnosis of Wegener's granulomatosis (90\%), but with a low specificity (50\%). ${ }^{[10]}$ The pANCA pattern 


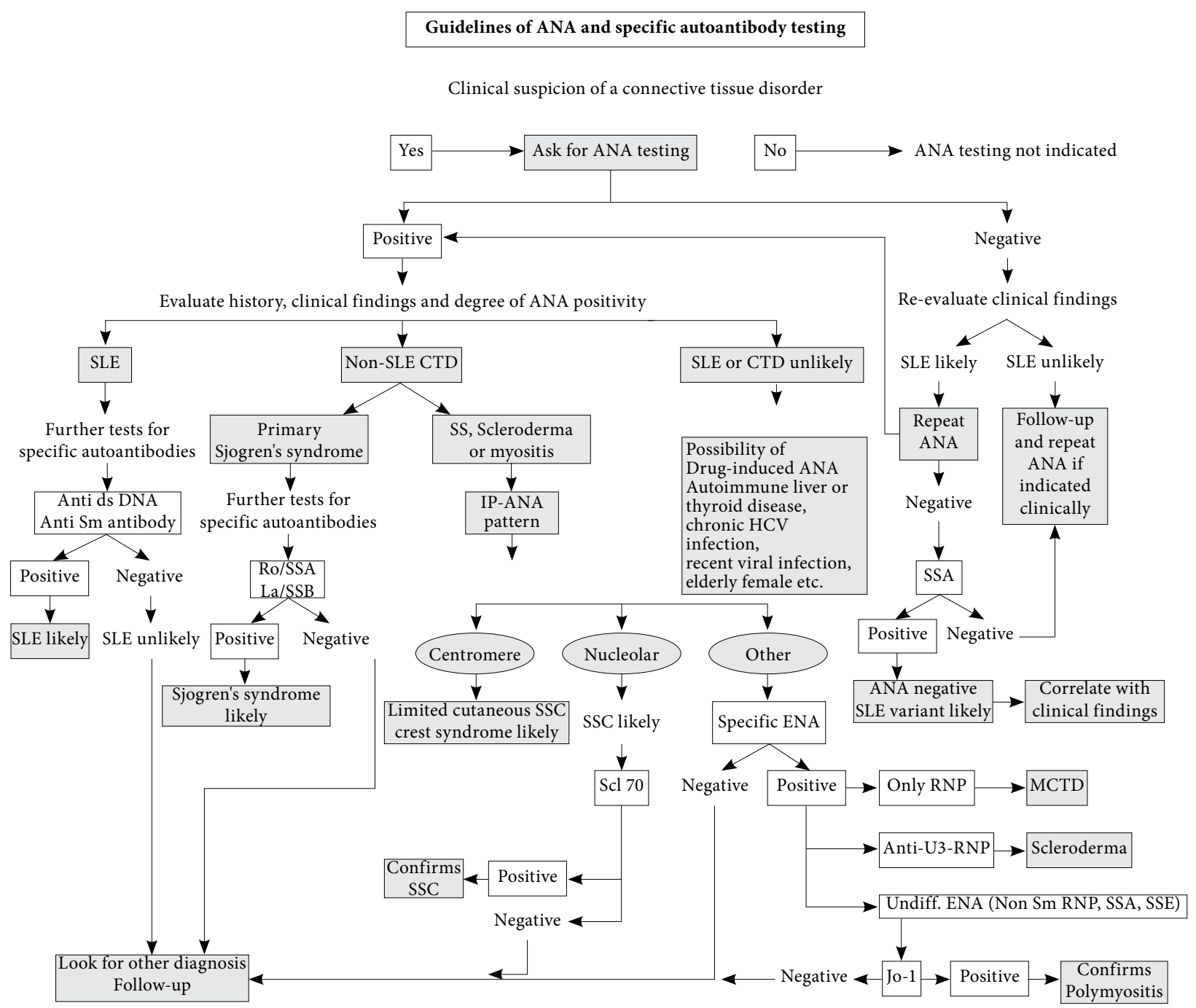

Figure 2. An algorithm of antinuclear antibodies and specific antibody testing in the diagnosis of rheumatic diseases. ${ }^{[6]}$

is found frequently in microscopic polyangiitis, Churg-Strauss syndrome, and pauci-immune glomerulonephritis, and sometimes in Wegener's granulomatosis. ${ }^{[38]}$

The myositis-specific antibodies are rarely used for the diagnosis of inflammatory myopathies; however, they can provide information about the manifestations of the disease once the diagnosis is made. ${ }^{[10]}$ The Jo-1 ANA can be detected in $25-30 \%$ of patients with dermatomyositis or polymyositis. It is associated with anti-synthetase syndrome manifesting with interstitial pulmonary disease and mechanic's hand. ${ }^{[39]}$ Anti-Mi2 antibodies are related to dermatomyositis and are predictive of a good prognosis. Anti-SRP is associated with cardiac disease and is unresponsive to the therapy. Anti-MAS is detected in rhabdomyolysis. ${ }^{[10]}$
A general approach to the diagnosis of RDs using generic ANA and specific antibody testing can be seen in Figure 2 on an algorithmic pathway. ${ }^{[6]}$

In conclusion ANA testing may provide important data for an upcoming rheumatic disease, be valuable in the diagnosis and prognosis prediction. Simply, ANA can be measured in two ways; one is the generic ANA for overall evaluation and the second is specific antibody detection for specific diseases. The immunofluorescence ANA testing is still gold standard for generic evaluation. If it is positive, specific antibodies can further be investigated by automated methods. Generic ANA is highly sensitive for systemic lupus erythematosus (SLE) and scleroderma, while its specificity is lower in these pathologies. In contrast specific antibodies are usually specific for related diseases with a low level of sensitivity. A competent 
clinician should well know the symptoms and clinical findings of the various RD's and should rationally use the laboratory findings as a supplementary diagnostic method.

\section{Acknowledgement}

I would like to thank to Dr. Deniz Doğan for his contribution during literature search and the technical support he provided.

\section{Declaration of conflicting interests}

The author declared no conflicts of interest with respect to the authorship and/or publication of this article.

\section{Funding}

The author received no financial support for the research and/or authorship of this article.

\section{REFERENCES}

1. Salamunic I. Laboratory diagnosis of autoimmune diseases-new technologies, old dilemmas. Biochemia Medica 2010;20:45-56.

2. Lernmark A. Autoimmune diseases: are markers ready for prediction? J Clin Invest 2001;108:1091-6.

3. Wiik AS, Gordon TP, Kavanaugh AF, Lahita RG, Reeves W, van Venrooij WJ, et al. Cutting edge diagnostics in rheumatology: the role of patients, clinicians, and laboratory scientists in optimizing the use of autoimmune serology. Arthritis Rheum 2004;51:291-8.

4. Satoh M, Vázquez-Del Mercado M, Chan EK. Clinical interpretation of antinuclear antibody tests in systemic rheumatic diseases. Mod Rheumatol 2009;19:219-28.

5. Villalta D, Tozzoli R, Tonutti E, Bizzaro N. The laboratory approach to the diagnosis of autoimmune diseases: is it time to change? Autoimmun Rev 2007;6:359-65.

6. Kumar Y, Bhatia A, Minz RW. Antinuclear antibodies and their detection methods in diagnosis of connective tissue diseases: a journey revisited. Diagn Pathol 2009;4:1.

7. Kavanaugh A, Tomar R, Reveille J, Solomon DH, Homburger HA. Guidelines for clinical use of the antinuclear antibody test and tests for specific autoantibodies to nuclear antigens. American College of Pathologists. Arch Pathol Lab Med 2000;124:71-81.

8. Meroni PL, Schur PH. ANA screening: an old test with new recommendations. Ann Rheum Dis 2010;69:1420-2.

9. Tan EM, Feltkamp TE, Smolen JS, Butcher B, Dawkins R, Fritzler MJ, et al. Range of antinuclear antibodies in "healthy" individuals. Arthritis Rheum 1997;40:1601-11.

10. Colglazier CL, Sutej PG. Laboratory testing in the rheumatic diseases: a practical review. South Med J 2005;98:185-91.

11. Bizzaro N, Tozzoli R, Tonutti E, Piazza A, Manoni F, Ghirardello A, et al. Variability between methods to determine ANA, anti-dsDNA and anti-ENA autoantibodies: a collaborative study with the biomedical industry. J Immunol Methods 1998;219:99-107.

12. Aarden LA, de Groot ER, Feltkamp TE. Immunology of DNA. III. Crithidia luciliae, a simple substrate for the determination of anti-dsDNA with the immunofluorescence technique. Ann N Y Acad Sci 1975;254:505-15.

13. D'Cruz D. Testing for autoimmunity in humans. Toxicol Lett 2002;127:93-100.

14. Bizzaro N, Tozzoli R, Shoenfeld Y. Are we at a stage to predict autoimmune rheumatic diseases? Arthritis Rheum 2007;56:1736-44.

15. Tozzoli R. Recent advances in diagnostic technologies and their impact in autoimmune diseases. Autoimmun Rev 2007;6:334-40.

16. Loong TW. Understanding sensitivity and specificity with the right side of the brain. BMJ 2003;327:716-9.

17. McGee S. Simplifying likelihood ratios. J Gen Intern Med 2002;17:646-9.

18. American College of Rheumatology Ad Hoc Committee on Immunologic Testing Guidelines. Guidelines for immunologic laboratory testing in the rheumatic diseases: an introduction. Arthritis Rheum 2002;47:429-33.

19. Mahler M, Hanly JG, Fritzler MJ. Importance of the dense fine speckled pattern on HEp-2 cells and anti-DFS70 antibodies for the diagnosis of systemic autoimmune diseases. Autoimmun Rev 2011. [Epub ahead of print]

20. Spencer-Green G. Outcomes in primary Raynaud phenomenon: a meta-analysis of the frequency, rates, and predictors of transition to secondary diseases. Arch Intern Med 1998;158:595-600.

21. Yazici Y. Role of laboratory tests in rheumatic disorders. In: Hochberg MC, Silman AJ, Smolen JS, Weinblatt $\mathrm{ME}$, Weisman $\mathrm{MH}$, editors. Rheumatology. 5th ed. Philadelphia: Elsevier Inc; 2011. p. 262-4.

22. Koffler D, Agnello V, Winchester R, Kunkel HG. The occurrence of single-stranded DNA in the serum of patients with systemic lupus erythematosus and other diseases. J Clin Invest 1973;52:198-204.

23. Kavanaugh AF, Solomon DH; American College of Rheumatology Ad Hoc Committee on Immunologic Testing Guidelines. Guidelines for immunologic laboratory testing in the rheumatic diseases: anti-DNA antibody tests. Arthritis Rheum 2002;47:546-55.

24. Schur PH. Laboratory evaluation of patients with systemic lupus erythematosus. In: Lahita RG, editor. Systemic lupus erythematosus. 4th ed. San Diego: Elsevier Inc; 2004. p. 633-44.

25. Eriksson C, Kokkonen H, Johansson M, Hallmans G, Wadell G, Rantapää-Dahlqvist S. Autoantibodies predate the onset of systemic lupus erythematosus in northern Sweden. Arthritis Res Ther 2011;13:R30.

26. Houtman PM, Kallenberg CG, Limburg PC, Huitema MG, van Rijswijk MH, The TH. Quantitation of antibodies to nucleoribonucleoprotein by ELISA: relation between antibody levels and disease activity in patients with connective tissue disease. Clin Exp Immunol 1985;62:696-704. 
27. Migliorini P, Baldini C, Rocchi V, Bombardieri S. Anti-Sm and anti-RNP antibodies. Autoimmunity 2005;38:47-54.

28. Ihn H, Yamane K, Yazawa N, Kubo M, Fujimoto M, Sato $S$, et al. Distribution and antigen specificity of antiU1RNP antibodies in patients with systemic sclerosis. Clin Exp Immunol 1999;117:383-7.

29. Vedove CD, Del Giglio M, Schena D, Girolomoni G. Drug-induced lupus erythematosus. Arch Dermatol Res 2009;301:99-105.

30. Gómez-Puerta JA, Burlingame RW, Cervera R. Antichromatin (anti-nucleosome) antibodies. Lupus 2006;15:408-11.

31. Muller S, Dieker J, Tincani A, Meroni PL. Pathogenic anti-nucleosome antibodies. Lupus 2008;17:431-6.

32. Fritzler MJ, Rattner JB, Luft LM, Edworthy SM, Casiano $\mathrm{CA}$, Peebles $\mathrm{C}$, et al. Historical perspectives on the discovery and elucidation of autoantibodies to centromere proteins (CENP) and the emerging importance of antibodies to CENP-F. Autoimmun Rev 2011;10:194-200.

33. Nakano M, Ohuchi Y, Hasegawa H, Kuroda T, Ito S, Gejyo F. Clinical significance of anticentromere antibodies in patients with systemic lupus erythematosus. J Rheumatol
2000;27:1403-7.

34. Miyawaki S, Asanuma $\mathrm{H}$, Nishiyama S, Yoshinaga Y. Clinical and serological heterogeneity in patients with anticentromere antibodies. J Rheumatol 2005;32:1488-94.

35. Ho KT, Reveille JD. The clinical relevance of autoantibodies in scleroderma. Arthritis Res Ther 2003;5:80-93.

36. Adnan ZA. Diagnosis and treatment of scleroderma. Acta Med Indones 2008;40:109-12.

37. Reveille JD, Solomon DH; American College of Rheumatology Ad Hoc Committee of Immunologic Testing Guidelines. Evidence-based guidelines for the use of immunologic tests: anticentromere, Scl-70, and nucleolar antibodies. Arthritis Rheum 2003;49:399-412.

38. Stone JH, Talor M, Stebbing J, Uhlfelder ML, Rose NR, Carson KA, et al. Test characteristics of immunofluorescence and ELISA tests in 856 consecutive patients with possible ANCA-associated conditions. Arthritis Care Res 2000;13:424-34.

39. Mammen AL. Autoimmune myopathies: autoantibodies, phenotypes and pathogenesis. Nat Rev Neurol 2011;7:34354. doi: 10.1038/nrneurol.2011.63. 